Crime, Histoire \& Sociétés / Crime, History \& Societies

Vol. 21, n² | 2017

L'histoire de la criminalité et de la justice pénale : propositions de recherche pour le $21^{\mathrm{e}}$ siècle

\title{
New Directions in the History of Criminology
}

\section{Richard F. Wetzell}

\section{(2) OpenEdition \\ Journals}

Electronic version

URL: http://journals.openedition.org/chs/2046

DOI: $10.4000 /$ chs.2046

ISSN: 1663-4837

Publisher

Librairie Droz

\section{Printed version}

Date of publication: 31 December 2017

Number of pages: 361-377

ISSN: $1422-0857$

\section{Electronic reference}

Richard F. Wetzell, "New Directions in the History of Criminology", Crime, Histoire \& Sociétés / Crime, History \& Societies [Online], Vol. 21, $n^{\circ} 2$ | 2017, Online since 19 July 2020, connection on 12 January 2021. URL: http://journals.openedition.org/chs/2046 ; DOI: https://doi.org/10.4000/chs.2046 


\title{
New Directions in the History of Criminology
}

\author{
Richard F. Wetzell
}

Tn the almost twenty years since Peter Becker and I convened a conference on

the history of criminology ${ }^{1}$, the field has witnessed a remarkable wave of new scholarship. This essay draws on the wealth of new research to reflect on some of the challenges facing historians of criminology: how to write a history of criminology that addresses the heterogeneity of expert discourses and embeds them within the larger context of discourses on crime in civil society; whether it is possible to develop a typology of criminological paradigms that might facilitate comparisons between countries and over time; how to conceptualize the nexus between criminological discourses, the criminal justice system and the emerging welfare state; how to tell the story of criminology as a transnational development.

\section{THE PLURALITY OF CRIMINOLOGICAL DISCOURSES}

Before the mid-twentieth century, criminology was not an academic discipline but a conglomerate of discourses deriving from different fields of knowledge and practice. Most contributors to discourses on crime and its causes were not trained "criminologists" but experts working in a variety of different fields. These included: statisticians, legal practitioners in criminal justice (judges, prosecutors, lawyers), professors of criminal law, police officials, professionals working in the prison system (prison administrators, prison doctors, prison chaplains), and medical doctors (especially psychiatrists). To indicate that criminology in this period was neither a science nor an academic discipline, we might, drawing on Foucault, call criminology a "discursive formation". Thus, the challenge for historians is that, at least until the middle of the twentieth century, criminological discourse - that is, statements on crime and its causes - was pluridisciplinary and heterogeneous ${ }^{3}$.

As a result, historians of criminology face their first hurdle when they try to define who counts as a criminologist ${ }^{4}$. In his recent survey of the history of criminology,

\footnotetext{
1 Revised contributions from the 1998 conference were published in Becker and Wetzell (2006).

2 Foucault (1972, p.31-39 and 178-181).

3 Some aspects of this heterogeneity are documented in Nicole Rafter's collection of nineteenth-century criminological texts: Rafter (2009).

4 For a comprehensive analysis of the issues involved in defining criminology for the purposes of writing a history of criminology, see A. Pires (1995).
} 
Pieter Spierenburg defines "a criminologist as an academically trained researcher whose work is devoted exclusively to the study of crime in the broadest sense" Using this definition, Spierenburg calls Lombroso the first criminologist ${ }^{6}$, whereas he labels the participants in pre-Lombrosian discourses on crime, including Cesare Beccaria and nineteenth-century moral statisticians, "pre-criminologists" "T The problem with Spierenburg's definition is that it disqualifies not only pre-Lombrosian contributors to discourses on crime but almost every post-Lombrosian contributor up to about 1945 as well because virtually none of them worked "exclusively" on the study of crime. Most of them were either medical doctors (usually psychiatrists or prison doctors), criminal jurists, statisticians, or sociologists, who worked on a variety of topics, of which criminological research was only one. Even the authors of major criminological works - Gabriel Tarde or Emile Durkheim in France, Gustav Aschaffenburg in Germany, Charles Goring in Britain - were either sociologists or physicians who were active in other areas of study ${ }^{8}$. Lombroso himself continued to publish on subjects unrelated to crime.

Given that before the mid-twentieth century almost no one devoted themselves exclusively to the study of crime, historians of criminology are well advised to cast a wide net by asking: Who contributed to discourses about crime and its causes in the era under investigation? A recent study using such a broad definition of criminology is Sabine Freitag's new study of British criminology, Kriminologie in der Zivilgesellschaft: Wissenschaftsdiskurse und die britische Öffentlichkeit, 1830-1945 (Criminology in civil society: scientific discourses and the British public) ${ }^{9}$. Freitag analyzes discourses on crime not just among a narrow group of experts but in a wide range of "discursive spaces", including statistics, empirical social research and social reform, medicine, especially psychiatry, the eugenics movement, psychology and psychoanalysis, and, last but not least, Britain's Prison Commission. By casting her net so widely, Freitag is able to challenge David Garland's landmark study Punishment and Welfare (1985), which claimed that the dominant "criminological program" in Great Britain from ca. 1895 to 1914 conceived of "criminality" as a pathological element of individual character ${ }^{10}$. Disagreeing with Garland, Freitag argues that, when the full range of discursive spaces is taken into account, it emerges that, from the mid-nineteenth all the way to the mid-twentieth century, "environmentalist" explanations of crime prevailed over biological and hereditarian ones. Moreover, her analysis of developments in civil society leads her to conclude that the trend toward environmentalist explanations of crime was connected to a broader political effort of "adjusting to democracy" by forming "rational, rounded citizens" 1 .

Spierenburg (2016, p.375).

6 On Lombroso, see Gibson (2002); on his reception in different countries, see Becker and Wetzell (2006); Knepper and Ystehede (2013).

7 Spierenburg (2016, p.375-378).

8 On Tarde, see Debuyst (1998); Mucchielli (1994a); Beirne (1993a); on Durkheim, see Digneffe (1998); on Aschaffenburg, see Wetzell (2000, p.63-71); Galassi (2004); Wetzell (2010); on Goring, see Davie (2005, p.229-268); Freitag (2014, p.233-282); Beirne (1993b).

9 Freitag (2014).

10 Garland (1985, p.93).

11 Freitag (2014, p.425-450). 


\section{CRIMINOLOGY AND CIVIL SOCIETY}

As Freitag's study shows, criminological discourses before the mid-twentieth century were not limited to experts in criminal justice, prisons, statistics, or psychiatry, but also included members of civil society who were interested in the problem of crime - such as members of social reform movements, volunteers in prisoner aid societies or journalists as well as artists, including writers, playwrights and film-makers, who addressed the topic of crime in their artistic work. Until the mid-twentieth century, at least, the boundaries between expert and non-expert discourses on crime were fluid. Historians therefore face the challenge of embedding the history of criminology in the larger context of social, cultural and political developments in civil society. Following the pioneering example of Martin Wiener's Reconstructing the Criminal: Culture, Law and Policy in England, 1830-1914, several recent studies, besides Freitag's, have contributed toward embedding criminology in the larger context of civil society ${ }^{12}$. Thus Mary Gibson has embedded her analysis of Lombroso and the Italian positivist school within the context of Italian society's attitudes and debates regarding gender and race as well as the political transition from liberalism to fascism ${ }^{13}$. Several recent books on Imperial Germany and the Weimar Republic have explored a multitude of discourses on crime that could be brought to bear on a more comprehensive history of criminology ${ }^{14}$. Likewise, recent work on press reporting on crime and criminal trials ${ }^{15}$ as well as recent studies of the portrayal of crime in literature and film ${ }^{16}$ have provided ample material for integrating the history of criminological discourses into the larger context of civil society and political culture.

Two aspects of the history of criminology that benefit greatly from being analyzed in the broader social and political context are the roles of gender and race. In addition to Gibson's aforementioned monograph, recent studies on the role of gender in the history of criminology include: Nicole Hahn Rafter and Gibson's new edition of Lombroso's Criminal woman, the prostitute, and the normal woman; Karsten Uhl's study of German criminological discourses on "criminal women" from 1800 to 1945; Martin Wiener's study of masculinity and violence in Victorian England; and Sharon Kowalski's study of female crime and criminology in Russia, 1880-1930 ${ }^{17}$. The role of race and ethnicity in criminological discourses has been examined in: Daniel Vyleta's analysis of how "Jewish criminality" was discussed in the antisemitic milieu of turnof-the-century Vienna; Michael Berkowitz's study of discourses on Jewish crime as well as his monograph on "the myth of Jewish criminality" in Nazi Germany; Volker Zimmermann's article on criminological analyses of Imperial Germany's Polish minority; Thomas Roth's study of penal policy in Nazi-era Cologne; and in some of the recent literature on the history of U.S. criminal justice and criminology ${ }^{18}$.

\footnotetext{
12 Wiener (1990).

13 Gibson (2002).

14 Lees (2002); Hett (2004); Müller (2005); Brückweh (2006); Elder (2010); Bischoff (2011); Ortmann (2014); Fitzpatrick (2015).

15 For surveys, see Wood (2016); Siemens (2016); Wood and Knepper (2014); recent monographs include Siemens (2007); Vyleta (2007); Wood (2012); Tribukait (2017).

16 Recent studies include Siebenpfeiffer (2005); Herzog (2009); Linder (2013); Hilgert (2013).

17 Lombroso (2004); Uhl (2003); Wiener (2004); Kowalsky (2009).

18 Vyleta (2007); Berkowitz (2006); Berkowitz (2007); Zimmermann (2017); Roth (2010, p.342-397);
} 


\section{DISCURSIVE SPACES}

The wide spectrum of "discursive spaces" studied by historians of criminology - including statistics, social reform associations, prisoner aid societies, the eugenics movement, and medicine - raises the question whether one could develop a typology of relevant discursive spaces that would allow us to compare their relative strength in different countries as a first step toward comparative analyses. A forthcoming article by Sabine Freitag and Desirée Schauz uses this method to offer an instructive comparison of the development of criminology and penal reform in Britain and Germany. Freitag and Schauz argue that Germany's penal reform movement was led by professors of criminal law, whereas in Britain legal academics played almost no role because Britain had no tradition of academic criminal law. By contrast, British discourses on crime and penal reform were dominated by voluntary associations, which were comparatively weak in Germany ${ }^{19}$. Thus in Germany criminological discourses and penal reform were dominated by academic discourses (both in criminal law and psychiatry), whereas in Great Britain they were mainly shaped by voluntary reform organizations reflecting a strong civil society that was interested in forming citizens equipped for political participation ${ }^{20}$. As Freitag and Schauz demonstrate, comparing the relative strength of different discursive spaces can be a promising strategy for developing systematic comparisons of the development of criminology in different countries. As a first step, historians of criminology might discuss whether, despite national differences and variations over time, we could assemble a list of relevant discursive spaces that could serve as the basis for such comparisons.

\section{TOWARD A TYPOLOGY OF CRIMINOLOGICAL PARADIGMS?}

A second strategy for generating productive comparisons of criminological discourses in different countries and time periods would be to develop a typology of what we might call criminological paradigms. In his study of criminology in nineteenth-century Germany, Peter Becker uses the term Erzählmuster (narrative pattern), rather than paradigm, to frame his central thesis. In the first half of the nineteenth century, he argues, practitioners in the field of policing, criminal justice, and prisons established a narrative pattern that regarded criminal offenders as "fallen men" (gefallene Menschen); this moralizing discourse blamed criminals for having made the decision to lead an immoral life. By contrast, in the late nineteenth century, new participants in criminological discourse - namely psychiatrists - introduced a new narrative that understood criminal offenders as "impaired men" (verhinderte Menschen), whose criminal behavior resulted from biological defects; the earlier moral discourse was replaced by a medico-scientific one ${ }^{21}$. As Thomas Kailer has argued in his study of Bavarian criminal-biological examinations, there is considerable

on the United States, see Alexander (2010) and Butler (2010).

19 On German prison societies, see Schauz (2008).

$20 \quad$ Freitag and Schauz (2019).

21 Becker (2002); for an English summary, see Becker (2006). 
evidence that the moralizing narrative of "fallen men" was not completely replaced by the medical narrative of "impaired men"; instead, a considerable degree of overlap continued to exist, and criminologists of the interwar era were often only cloaking moral judgments in medical language ${ }^{22}$. The same duality of medical and moral patterns of argumentation also characterized the Nazi period ${ }^{23}$.

Nevertheless, Becker's two narrative patterns provide a useful starting point for developing a more comprehensive typology of criminological paradigms in order to facilitate comparisons across borders and time periods. Since Thomas Kuhn introduced the term "paradigm" as a heuristic device for the history of science ${ }^{24}$, it could be argued that the term "paradigm" should not be applied to criminological discourses because criminology was not a scientific discipline until the mid-twentieth century, at the earliest. I would argue, however, that if we are searching for a term to denote patterns in how crime is explained, "paradigm" is more apt than "narrative pattern" because some types of criminological research, especially statistical and medical research, do not necessarily take the form of narratives.

As a first draft for a typology of explanations of crime I would propose four criminological paradigms: first, explaining crime as the result of a moral failing; second, explaining crime as the result of a criminogenic biological defect in the offender; third, explaining crime as a resulting from a mixture of biological and environmental factors (through degeneration theory, for instance); and fourth, explaining crime as the result of environmental factors.

Needless to say, these four paradigms are rough approximations. The first is identical with Becker's moralistic narrative of "fallen men". Becker's second narrative pattern, however, that of "impaired men", has been divided into two different paradigms here in order to distinguish between discourses that attribute crime directly to a criminogenic biological trait, and those that attribute crime to a mixture of biological and environmental factor ${ }^{25}$. This distinction, I would argue, is crucial to understanding the debates between Lombroso and most of his European critics. Whereas Lombroso and a minority of European psychiatrists believed in a criminogenic defect (using the concept of "born criminal" or "moral insanity", for instance), the majority of medical doctors pursuing criminological research (including Gustav Aschaffenburg in Germany, Charles Goring in Britain, and Alexandre Lacassagne in France) conceptualized the connection between crime and abnormality as a complex interaction of environmental factors acting on mental abnormalities that were not inherently criminogenic ${ }^{26}$. This third paradigm could take on quite different forms depending on whether the biological or the environmental factors were stressed.

The fourth, "environmentalist" paradigm generated optimism about society's

\footnotetext{
$22 \quad$ Kailer (2011, p.29 and 86-89).

23 Wetzell (2000, p.179-231).

24 Kuhn (1962).

25 The second and third paradigms are generalized versions of what, in my study of German criminology, I called the "Kraepelin" and "Aschaffenburg" paradigms, after their primary representatives in Germany: see Wetzell (2000, p.68-71).

26 On the reception of Lombroso in France, see Renneville (2013); Mucchielli (2006); Renneville (2003); Kaluszynski (2002); Debuyst (1998); Mucchielli (1994b); on Goring and Lombroso's reception in Britain, see Davie (2013); Freitag (2014); Davie (2005).
} 
ability to rehabilitate offenders and to prevent crime by ameliorating social conditions. What one might ponder is whether the environmentalist paradigm should be divided into different subtypes in order to distinguish environmentalist discourses focusing on the individual offender ${ }^{27}$ from those that approach crime as a collective social phenomenon, or to distinguish between the types of environmental factors stressed (economic factors versus a personal milieu, for instance).

The typology of criminological paradigms proposed here is, of course, only a sketch that would have to be refined by a collaborative effort of historians of criminology with expertise in different countries and eras. Even though such a typology could never capture all the nuances of specific historical situations, it would facilitate systematic comparison between countries and time periods as well as the analysis of transnational criminological debates.

\section{AN INTEGRATED HISTORY OF CRIMINOLOGY, CRIMINAL JUSTICE, AND THE WELFARE STATE}

Another challenge for historians of criminology is posed by the nexus between criminology, the criminal justice system, and the modern welfare state. The criminological quest to uncover the causes of crime has always been closely connected to efforts to combat crime more effectively. Not only were many participants in criminological discourse practitioners in the criminal justice system, the police, and the prison system; most criminological research explicitly sought to provide guidance for improving society's defense against crime. While some criminologists argued that this was best achieved through social reforms outside the criminal justice system, most focused on research questions designed to make policing, criminal justice, and prisons more effective. Thus, in the late nineteenth century, many criminologists and penal reformers called for the individualization of the penal sanction by introducing a spectrum of new sanctions designed to offer alternatives to imprisonment for certain categories of offenders. These new penal sanctions included education for juveniles, suspended sentences for certain first-time offenders, psychiatric treatment for mentally abnormal offenders ${ }^{28}$, detoxification for alcoholic offenders, and indefinite detention for incorrigible habitual offenders ${ }^{29}$. By integrating education, medical treatment, and administrative detention into the arsenal of penal sanctions, and by calling on welfare agents to work with the criminal courts $^{30}$, this reform programme was effectively merging criminal justice with welfare measures, resulting in what David Garland has called "the penal-welfare complex" 31 . For this reason, the development of criminology is closely connected not only to criminal justice but also to the modern interventionist welfare state.

27 Compare David Garland's comments about environmentalists who "took as their object the criminal individual as affected by social factors”. See Garland (1985, p.175).

28 On the treatment of sex offenders, see Eghigian (2015).

29 On indeterminate sentencing and the dual-track system, see Pifferi (2016).

30 On the German efforts to draw on welfare agents in criminal court proceedings, see Rosenblum (2008).

31 Garland (1985); see also Garland (2001). 
Historians seeking to analyze this connection face not only empirical but also conceptual challenges. Characterizing criminology as an "applied science" implies that criminology drew on a recognized body of scientific knowledge to develop practical applications for criminal justice. Criminology, however, had no such recognized body of knowledge to draw on. Instead, the relationship was one of mutual influence: On the one hand, criminological research was motivated by penal reformers' search for more effective methods of combating crime. The problem of recidivism and the desire to distinguish between corrigible and incorrigible offenders, for instance, provided an agenda for much criminological research. On the other hand, some results of criminological research affected the course of penal reform. In what follows I shall briefly examine two concepts that have been used to conceptualize the relationship of criminology to criminal justice and the welfare state.

\section{Medicalization}

One of the ways in which historians have conceptualized the nexus between criminology and criminal justice has been to use the concept of "medicalization" 32 , which has featured prominently in the historiography of French and Swiss criminal justice $^{33}$ and been debated controversially in the German historiography ${ }^{34}$. If the standard for medicalization is the radical vision that criminality be treated like mental illness, that judicial verdicts be replaced by psychiatric evaluations, and that prisons become mental hospitals, then one cannot apply the term "medicalization" to the history of late-nineteenth and early-twentieth-century criminal justice in any European country. Thus Christian Müller has argued that one cannot speak of the medicalization of German criminal justice in this era because Franz von Liszt, the leader of German penal reform, contained the medical challenge by incorporating elements of psychiatric research into his reform agenda in order to bolster the legal profession's authority: the judge, not the psychiatrist, would retain the authority to determine the sentence ${ }^{35}$. By contrast, I would argue that defining "medicalization" as the capitulation of jurists to a psychiatric takeover of criminal justice sets the bar too high. Instead, historians should ask the question: Did medical doctors exert an increasing influence on penal policy and the criminal justice system? If the question is posed this way, one can generate empirical criteria for determining whether, in a given country at a particular time, there is evidence for the medicalization of criminal justice, and if so, to what degree.

In the case early-twentieth-century Germany, I would argue, there is some evidence for this process: Firstly, German penal reformers looked to psychiatrists for insights into the causes of crime and for medical solutions to the crime problem; psychiatrists' claims that many criminals suffered from mental abnormalities were widely accepted among jurists. Secondly, psychiatrists convinced most jurists that the classic all-or-nothing approach to legal responsibility had to give way to the

\footnotetext{
32 On the concept, see Frevert (1984); Loetz (1994); Nye (2003); Germann (2004, p.27-31).

33 On France, see Nye (1984); on Switzerland, see Germann (2004).

34 For the major interventions, see Wetzell (1996); C. Müller (2004); Galassi (2004); Schauz and Freitag (2007); Schauz (2007); Wetzell (2008); Wetzell (2009); Schauz (2010).

35 C. Müller (2004, p.125-126; 133-135 and 168-169).
} 
introduction of "diminished responsibility". Thirdly, jurists accepted psychiatrists' recommendation that penal sanctions for mentally abnormal offenders must include medical treatment. This amalgamation of the penal sanction with medical treatment was a transformative development ${ }^{36}$. Finally, the introduction of criminal-biological examinations in German prisons gave doctors the power to determine the treatment of criminals in prison and, if released prisoners re-offended, to influence their judicial treatment in $\operatorname{court}^{37}$.

While these developments did not amount to a complete medicalization of criminal justice, they reflected a medicalization process in the sense that medical approaches became significantly more influential in the German criminal justice system ${ }^{38}$. This process benefitted both penal reformers and doctors. While the medical profession expanded its professional terrain, penal reformers used medical theories to sharpen their attack on the classical school of criminal law and buttressed their own authority by incorporating psychiatric theories into their reform agenda. The situation in Great Britain and France was certainly different ${ }^{39}$, although Martin Wiener and Robert Nye have demonstrated the importance of medical discourses in the field of penal reform in those countries as well ${ }^{40}$.

\section{The Scientization of the Social}

Another approach to making sense of the relationship of criminology to criminal justice and welfare has been to use the concept of "the scientization of the social". This approach has been especially prominent in German historiography, which has been influenced by a 1996 article by Lutz Raphael, in which he coined the phrase "scientization of the social" (Verwissenschaftlichung des Sozialen) to describe the increasing influence that "experts" in the human sciences came to wield in state and society since the late nineteenth century ${ }^{41}$. At first glance, it seems that the history of criminology fits this general interpretive pattern quite well. In her history of criminology in Imperial Germany, however, Silviana Galassi objected that turnof-the-century German criminological discourse was strongly shaped by moral judgments and legal categories, and was therefore not a "science"; and that hence it could hardly be part of a process of the "scientization of the social" is correct that the criminological discourse of this era conflated medical, moral, and legal categories, this should not, in my view, prevent historians from contextualising the development of criminology as part of what contemporaries understood as a "scientization" of criminal justice. For turn-of-the-century penal reformers were quite explicitly intent on reforming criminal justice by basing penal policy not primarily on moral or legal philosophy but on empirical scientific knowledge about the causes of crime and the best way to prevent crime. The task they set for themselves was

\footnotetext{
36 For a more detailed account of these points, see Wetzell (2000, p. 73-105).

37 See Kailer (2011).

38 For a more comprehensive version of my argument, see Wetzell (2008) and Wetzell (2009).

39 On France, see Kaluszynki (2002) and Mucchielli (1994b); on Britain, see Freitag (2014).

40 Wiener (1990), Nye (1984).

41 Raphael (1996); see also Ziemann, Wetzell et al. (2012).

42 Galassi (2004, esp. p. 421-423); see also Freitag and Schauz (2007).
} 
to translate the empirical findings of criminological research - regarding causes of crime, distinctions between different types of criminals, and the most effective penal sanctions - into a revision of the penal code that would transform criminal justice, including a completely new system of sanctions ${ }^{43}$.

To be sure, the jurists who led the penal reform effort wanted to remain in control of this process, and there were sometimes fierce boundary disputes between jurists, psychiatrists, and welfare officials. Nevertheless, the jurists were eager to draw on criminological research and envisaged an increased role for criminological experts in the new criminal justice system. The challenge for the historian of criminology is to convey the penal reformers' intent to provide criminal justice with a scientific basis, while recognizing that the criminological knowledge they drew on was inextricably interwoven with the moral assumptions and legal practices of the time. In short, the historical process of the "scientization of the social" was a process marked by multidirectional influences between penal (and social) reform and the scientific knowledge that was drawn on to legitimate and guide these reform efforts. In order to better capture these multidirectional influences, historians of criminology might wish to take a closer look at the burgeoning historical literature on the "history of knowledge", which seeks to examine the role of knowledge not just in scientific but also in extra-scientific contexts. Since criminological discourses were never purely academic but situated at the boundaries between academia, criminal justice, the welfare state, and civil society, approaching criminology with the tools of the history of knowledge, rather than the history of science, might yield new insights ${ }^{44}$.

\section{CRIMINOLOGY AS A TRANSNATIONAL ENDEAVOR}

The development of criminology was a transnational phenomenon. Since most historians are trained in the history of a particular country, most histories of criminology are national histories. This is perfectly legitimate and facilitates drawing out the connections between criminology, criminal justice, welfare, and broader social and political developments in a national context. Nevertheless, there are several reasons why the history of criminology cannot be understood without the transnational dimension. Firstly, already in the first half of the nineteenth century, the criminal jurists, prison reformers, and statisticians who participated in discourses on crime took part in transnational networks of scholarly exchange through letters, journeys abroad, and, starting in the 1840s, international congresses; the first international prison congress took place in $1846^{45}$. Secondly, the trend toward organizing international congresses on various aspects of social and penal reform only accelerated in the last third of the nineteenth century ${ }^{46}$, which witnessed the

43 Wetzell (2000, p. 31-38); Wetzell (2004).

44 On the history of knowledge, see Burke (2015), Lässig (2016); see also Schauz (2010), who suggests framing criminology as a form of "Mode 2" production of knowledge; on "Mode 2", see Nowotny, Scott, and Gibbons (2003).

45 On the first prison congresses, in the 1840s, see Riemer (2004); on epistolary networks among prison reformers in the period 1830-1870, see Riemer (2005).

46 On this development, see Saunier (2008); Ziemann et al. (2012, p. 15-16), Geyer and Paulmann (2001). 
organization of regular congresses on criminal anthropology, prison reform, and criminal law reform. Thirdly, the 1876 publication of Cesare Lombroso's Criminal $\mathrm{Man}^{47}$ provided a powerful impulse to criminological research in many countries, so that criminology truly became a transnational endeavor. Finally, the late nineteenth century witnessed the emergence of growing concern about "international crime" as a problem that could only be addressed by international cooperation ${ }^{48}$. For these reasons, individual historians face the challenge of embedding the history of criminology in any given country within its transnational context, and, collectively, we face the task of investigating and analyzing the transnational history of criminology.

The international congresses most directly connected to criminology were the International Congresses of Criminal Anthropology between 1886 and 1914, which are famous for the clash between the Italian and French schools, analyzed in a pioneering article by Robert Nye ${ }^{49}$. While Martine Kaluszynski has provided a brief analysis of the functions and structure of these congresses ${ }^{50}$, we still do not have a comprehensive historical account tracing the trajectory of the major debates at these congresses. In the meantime, we have learned more about two other international networks that also addressed criminological matters. The Prison Congresses organized by the International Prison Commission, which took place roughly every five years from 1872 to 1935 , focused on prison reform but increasingly took up other aspects of penal reform including criminological questions. The Union Internationale de Droit Pénal (in German: Internationale Kriminalistische Vereinigung; hereafter: IKV), which was founded by three criminal law professors (van Hamel, Prins, von Liszt) and held twelve international congresses between 1889 and 1914, was the era's most active penal reform organization and addressed criminological questions more directly than the prison congresses. After the First World War, lingering FrancoGerman hostility prevented the resurrection of the IKV, and the French founded a new organization, the Association Internationale de Droit Pénal.

Recent work has begun to elucidate the role of these transnational networks in the history of criminology and penal reform. Martina Henze has provided an excellent overview of the organizational history of all three networks ${ }^{51}$. Clive Emsley's recent survey addresses the transnational dimension of the history of criminal justice in modern Europe $^{52}$. Sylvia Kesper-Biermann and Petra Overath ${ }^{53}$, Tiago Pires Marques $^{54}$, and Urs Germann ${ }^{55}$ have published studies of penal reform in Germany, Italy, and Switzerland, respectively, that pay particular attention to the transnational

47 We now have a superb English edition, prepared by Mary Gibson and Nicole Rafter, with a historical introduction and a comparison of the different Italian editions: Lombroso (2006); on Lombroso, see Gibson (2002).

48 See Knepper (2010) and Jäger (2006).

49 Nye (1976).

50 Kaluszynski (2006).

51 Henze (2009).

52 Emsley (2007).

53 Kesper-Biermann and Overath (2007).

54 Marques (2013); see also Marques (2018).

55 Germann (2014). 
arena. In addition, Kesper-Biermann has charted the history of the IKV ${ }^{56}$; I have analyzed Franz von Liszt's positions in some of the IKV's transnational debates ${ }^{57}$; and, most recently, Michele Pifferi has written a comparative study of penal reform, focusing on the issue of indeterminate sentencing, that draws on the debates at international congresses as one of its major sources ${ }^{58}$. Nevertheless, much historical research on the transnational aspect of the history of criminology remains to be done. The remaining tasks include charting the trajectory of particular subjects discussed at these congresses over several decades; relating such transnational discussions to developments in individual countries; and teasing out the criminological assumptions underlying a variety of penal reform proposals ${ }^{59}$.

\author{
Richard F. Wetzell \\ German Historical Institute \\ Washington DC \\ wetzell@ghi-dc.org
}

\title{
BIBLIOGRAPHY
}

Alexander, M. (2010) The New Jim Crow: Mass Incarceration in the Age of Colorblindness, New York: New Press.

Becker, P. (2002) Verderbnis und Entartung: Eine Geschichte der Kriminologie des 19. Jahrhunderts als Diskurs und Praxis, Göttingen: Vandenhoeck \& Ruprecht.

Becker, P. (2006) "The criminologists" gaze at the Underworld: toward an archaeology of criminological writing, in Becker, P. and Wetzell, R. (Eds.), Criminals and Their Scientists: The History of Criminology in International Perspective, Cambridge/New York: Cambridge University Press.

Becker, P. and Wetzell, R. (Eds.) (2006) Criminals and Their Scientists: The History of Criminology in International Perspective, Cambridge/New York: Cambridge University Press.

Beirne, P. (1993a) "Between God and statistics: Gabriel Tarde and neoclassical criminology", in Beirne, P. (Ed.), Inventing Criminology: Essays on the Rise of "homo criminalis", Albany: State University of New York Press.

Beirne, P. (1993b) Science, statistics and eugenics in Charles Goring's The English Convict (1913), in Beirne, P. (Ed.), Inventing Criminology: Essays on the Rise of "homo criminalis", Albany: State University of New York Press.

Berkowitz, M. (2006) Unmasking counter history: An introductory exploration of criminality and the Jewish question, in Becker, P. and Wetzell, R. (Eds.), Criminals and Their Scientists: The History of Criminology in International Perspective, Cambridge/New York: Cambridge University Press.

\footnotetext{
56 Kesper-Biermann (2007).

57 Wetzell (2016).

58 Pifferi (2016).

59 A transnational and comparative perspective on the history of criminal justice in modern Europe, 1870-1970, will be provided in the forthcoming edited volume: Wetzell (2019).
} 
Berkowitz, M. (2007) The Crime of my Very Existence: Nazism and the Myth of Jewish Criminality, Berkeley: University of California Press.

Bischoff, E. (2011) Kannibale-Werden: Eine postkoloniale Geschichte deutscher Männlichkeit um 1900, Bielefeld: transcript.

Brückweh, K. (2006) Mordlust: Serienmorde, Gewalt und Emotionen im 20. Jahrhundert, Frankfurt: Campus.

Burke, P. (2015) What is the History of Knowledge?, London: Polity.

Butler, P. (2010) One hundred years of race and crime, Journal of Criminal Law and Criminology, 100, 3, p. 1043-1060.

Davie, N. (2005) Tracing the Criminal: The Rise of scientific Criminology in Britain, 18601918, Oxford: Bardwell Press.

Davie, N. (2013) Lombroso and the "men of real science": British reactions, 1886-1918, in Knepper, P. and Ystehede, P.J. (Eds.), The Cesare Lombroso Handbook, London, Routledge, p. 342-360.

Debuyst, C. (1998) L'école française dite "du milieu social”, in Debuyst, C., Digneffe, F., Labadie, J.M. and Pires, A.P. (Eds.), Histoire des savoirs sur le crime et la peine. Tome 2: La Rationalité pénale et la naissance de la criminologie, Ottawa/Bruxelles: Les Presses de l'Université de Montréal \& Université d'Ottawa \& De Boeck.

Digneffe, F. (1998) Durkheim et les débats sur le crime et la peine, in Debuyst, C., Digneffe, F., Labadie, J.M. and Pires, A.P. (Eds.), Histoire des savoirs sur le crime et la peine. Tome 2: La rationalité pénale et la naissance de la criminologie. Ottawa/Bruxelles: Les Presses de l'Université de Montréal \& Université d'Ottawa \& De Boeck.

Eghigian, G. (2015) The Corrigible and the Incorrigible: Science, Medicine, and the Convict in Twentieth-Century Germany, Ann Arbor: University of Michigan Press.

Elder, S. (2010) Murder Scenes: Normality, Deviance, and Criminal Violence in Weimar Berlin, Ann Arbor: University of Michigan Press.

Emsley, C. (2007) Crime, Police, and Penal Policy: European Experiences 1750-1940, Oxford: Oxford University Press.

Fitzpatrick, M. (2015) Purging the Empire: Mass Expulsions in Germany, 1871-1914, Oxford: Oxford University Press.

Foucault, M. (1972) The Archaeology of Knowledge, New York: Pantheon Books.

Freitag, S. (2014) Kriminologie in der Zivilgesellschaft: Wissenschaftsdiskurse und die britische Öffentlichkeit, 1830-1945, Munich: Oldenbourg Verlag.

Freitag, S. and Schauz, D. (2007) Verbrecher im Visier der Experten: Zur Einführung, in Schauz and Freitag, eds., Verbrecher im Visier der Experten: Kriminalpolitik zwischen Wissenschaft und Praxis im 19. und frühen 20. Jahrhundert, Stuttgart: Steiner.

Freitag, S. and Schauz, D. (forthcoming, 2019) Civil Society or Academia? British and German Penal Reform Associations and Their Relation to the Emerging Science of Criminology, in Wetzell, R. (Ed.), Criminal Justice in Modern Europe, 1870-1970, Cambridge: Cambridge University Press.

Frevert, U. (1984) Krankheit als politisches Problem 1770-1880, Göttingen, Vandenhoeck \& Ruprecht.

Galassi, S. (2004) Kriminologie im deutschen Kaiserreich: Geschichte einer gebrochenen Verwissenschaftlichung, Stuttgart: Steiner Verlag. 
Garland, D. (1985) Punishment and Welfare: A History of Penal Strategies, Aldershot: Gower.

Garland, D. (2001) Modern criminal justice and the penal-welfare state, in Garland, D. (Ed.), The Culture of Control: Crime and Social Order in Contemporary Society, Chicago: University of Chicago Press.

Germann, U. (2004) Psychiatrie und Strafjustiz: Entstehung, Praxis und Ausdifferenzierung der forensischen Psychiatrie am Beispiel der deutschsprachigen Schweiz 1850-1950, Zurich: Chronos.

Germann, U. (2014) Kampf dem Verbrechen: Kriminalpolitik und Strafrechtsreform in der Schweiz, 1870-1950, Zurich: Chronos.

Geyer, M. and Paulmann, J. (Eds.) (2001) The Mechanics of Internationalism: Culture, Society, and Politics from the 1840s to the First World War, Oxford: Oxford University Press.

Gibson, M. (2002) Born to Crime: Cesare Lombroso and the Origins of Biological Criminology, Westport: Praeger.

Henze, M. (2009) Crime on the agenda: transnational organizations 1870-1955, Historisk Tidsskrift, 109, 2, p. 369-417.

Herzog, T. (2009) Crime Stories: Criminalistic Fantasy and the Culture of Crisis in Weimar Germany, New York: Berghahn Books.

Hilgert, N. (2013) Unterhaltung, aber sicher!: Populäre Repräsentationen von Recht und Ordnung in den Fernsehkrimis »Stahlnetz« und »Blaulicht«, 1958/59-1968, Bielefeld: transcript.

Hett, B. (2004) Death in the Tiergarten: Murder and Criminal Justice in the Kaiser's Berlin, Cambridge, Mass.: Harvard University Press.

Jäger, J. (2006) Verfolgung durch Verwaltung: Internationales Verbrechen und internationale Polizeikooperation 1880-1933, Konstanz: UVK.

Kailer, T. (2011) Vermessung des Verbrechers: Die Kriminalbiologische Untersuchung in Bayern, 1923-1945, Bielefeld: transcript.

Kaluszynski, M. (2002) La République à l'épreuve du crime: La construction du crime comme objet politique 1880-1920, Paris: LGDJ.

Kaluszynski, M. (2006) The international congresses of criminal anthropology: shaping the French and international criminological movement, 1886-1914, in Becker, P. and Wetzell, R. (Eds.), Criminals and Their Scientists: The History of Criminology in International Perspective, Cambridge/New York: Cambridge University Press.

Kesper-Biermann, S., (2007) Die internationale kriminalistische Vereinigung: zum Verhältnis von Wissenschaftsbeziehungen und Politik im Strafrecht 1889-1932, in Kesper-Biermann, S. and Overath, P. (Eds.), Die Internationalisierung von Strafrechtswissenschaft und Kriminalpolitik (1870-1930): Deutschland im Vergleich, Berlin: Berliner Wissenschaftsverlag.

Kesper-Biermann, S. and Overath, P. (Eds.), (2007) Die Internationalisierung von Strafrechtswissenschaft und Kriminalpolitik (1870-1930): Deutschland im Vergleich, Berlin: Berliner Wissenschaftsverlag.

Knepper, P. (2010) The Invention of International Crime: A Global Issue in the Making, 18811914, Houndmills: Palgrave Macmillan.

Knepper, P. and Ystehede, P.J. (Eds.) (2013) The Cesare Lombroso Handbook, London: Routledge. 
Kowalsky, S. (2009) Deviant Women: Female Crime and Criminology in Revolutionary Russia, 1880-1930, Dekalb: Northern Illinois University Press.

Kuhn, T. (1962) The Structure of Scientific Revolutions, Chicago: University of Chicago Press.

Lässig, S. (2016) The History of Knowledge and the Expansion of the Historical Research Agenda, Bulletin of the German Historical Institute, Fall 2016, 59, p. 29-58.

Lees, A. (2002) Cities, Sin, and Social Reform in Imperial Germany, Ann Arbor: University of Michigan Press.

Linder, J. (2013) Wissen über Kriminalität: Zur Medien- und Diskursgeschichte von Verbrechen und Strafjustiz vom 18. bis zum 21. Jahrhundert, Würzburg: Ergon.

Loetz, F. (1994) "Medikalisierung” in Frankreich, Großbritannien und Deutschland, 17501850: Ansätze, Ergebnisse und Perspektiven der Forschung, in Eckhart, W. and Jütte, R. (Eds.), Das europäische Gesundheitssystem, Stuttgart: Steiner Verlag.

Lombroso, C. (2004) Criminal Woman, the Prostitute, and the Normal Woman, translated and with a new introduction by Rafter, N. and Gibson, M., Durham: Duke University Press.

Lombroso, C. (2006) Criminal Man, translated and with a new introduction by Gibson, M. and Rafter, N., Durham: Duke University Press.

Marques, T.P. (2013) Crime and the Fascist State, 1850-1940, London: Pickering \& Chatto.

Marques, T.P. (forthcoming 2018) Codifying dangerousness at the transnational crossroads, c. 1870-1930, in Wetzell, R. (Ed.), Criminal Justice in Modern Europe, 1870-1970, Cambridge: Cambridge University Press.

Mucchielli, L. (1994a) Naissance et déclin de la sociologie criminelle (1890-1940), in Mucchielli, L. (Ed.), Histoire de la criminologie française, Paris: L'Harmattan.

Mucchielli, L. (Ed.) (1994b) Histoire de la criminologie française, Paris: L'Harmattan.

Mucchielli, L. (2006) Criminology, hygienism, and eugenics in France, 1870-1914: the medical debates on the elimination of "incorrigible" criminals, in Becker, P. and Wetzell, R. (Eds.), Criminals and Their Scientists: The History of Criminology in International Perspective, Cambridge/New York: Cambridge University Press.

Müller, C. (2004) Verbrechensbekämpfung im Anstaltsstaat: Psychiatrie, Kriminologie und Strafrechtsreform in Deutschland 1871-1933, Göttingen: Vandenhoeck \& Ruprecht.

Müller, P. (2005) Auf der Suche nach dem Täter: Die öffentliche Dramatisierung von Verbrechen im Berlin des Kaiserreichs, Frankfurt: Campus.

Nowotny, H., Scott, P. and Gibbons, M. (2003) Introduction: "Mode 2" revisited: the new production of knowledge, Minerva, 41, p. 179-194.

Nye, R. (1976) Heredity or milieu: The foundations of modern European criminological theory, Isis, 67, 3, p. 334-355.

Nye, R. (1984) Crime, Madness and Politics in Modern France: The Medical Concept of National Decline, Princeton: Princeton University Press.

Nye, R. (2003) The evolution of the concept of medicalization in the late twentieth century, Journal of the History of the Behavioral Sciences, 39, 2, p. 115-129.

Ortmann, A. (2014) Machtvolle Verhandlungen: Zur Kulturgeschichte der deutschen Strafjustiz. 1879-1924, Göttingen: Vandenhoeck \& Ruprecht.

Pifferi, M. (2016) Reinventing Punishment: A Comparative History of Criminology and Penology in the 19th and 20th Century, Oxford: Oxford University Press. 
Pires, A. (1995) La Criminologie d'hier et d'aujourd'hui, in Debuyst, C., Digneffe, F., Labadie, J.M., Pires, A.P. (Eds.), Histoire des savoirs sur le crime et la peine. Tome I: Des savoirs diffus à la notion de criminel-né, Ottawa/Bruxelles: Les Presses de l'Université de Montréal \& Université d'Ottawa \& De Boeck, p. 13-67.

Rafter, N. (Ed.) (2009) The Origins of Criminology: A Reader, London: Routledge.

Raphael, L. (1996) Die Verwissenschaftlichung des Sozialen als methodische und konzeptionelle Herausforderung für eine Sozialgeschichte des 20. Jahrhunderts, Geschichte und Gesellschaft, 22, 2, p. 165-193.

Renneville, M. (2003) Crime et folie: deux siècles d'enquêtes médicales et judiciaires, Paris: Fayard.

Renneville, M. (2013) Lombroso in France: a paradoxical reception, in Knepper, P. and Ystehede, P.J. (Eds.), The Cesare Lombroso Handbook, London: Routledge, 2013.

Riemer, L. (2004) Areopag der Wissenschaft Die Behandlung gesellschaftlicher Krisen auf Fachtagungen des Vormärz am Beispiel der ersten internationalen Gefängniskongresse, in Kretschmann, C., Pahl, H. and Scholz, P. (Eds.), Wissen in der Krise: Institutionen des Wissens im gesellschaftlichen Wandel, Berlin: Akademie Verlag.

Riemer, L. (2005) Das Netzwerk der „Gefängnisfreunde“ (1830-1872): Karl Josef Anton Mittermaiers Briefwechsel mit europäischen Strafvollzugsexperten, Frankfurt: Klostermann.

Rosenblum, W. (2008) Beyond the Prison Gates: Punishment and Welfare in Germany, 18501933, Chapel Hill: University of North Carolina Press.

Roth, T. (2010) Verbrechensbekämpfung und soziale Ausgrenzung im nationalsozialistischen Köln: Kriminalpolizei, Strafjustiz und abweichendes Verhalten zwischen Machtübernahme und Kriegsende, Köln: Emons.

Saunier, P.Y., (2008) Les régimes circulatoires du domaine social 1800-1940: projets et ingénierie de la convergence et de la différence, Genèses, 71, 2, p. 4-25.

Schauz, D. (2008) Strafen als moralische Besserung: Eine Geschichte der Straffälligenfürsorge 1777-1933, Munich: Oldenbourg.

Schauz, D. (2007) Straffälligenfürsorge und Kriminologie: Wege und Grenzen der Verwissenschaftlichung, in Schauz, D. and Freitag, S. (Eds.), Verbrecher im Visier der Experten: Kriminalpolitik zwischen Wissenschaft und Praxis im 19. und frühen 20. Jahrhundert, Stuttgart: Steiner Verlag.

Schauz, D. (2010) Zum Verhältnis von Kriminologie und Kriminalpolitik: Die transdisziplinäre Genese der deutschen Kriminologie, in Pieper, C. and Uekötter, F. (Eds.), Vom Nutzen der Wissenschaft, Stuttgart: Steiner Verlag.

Schauz, D. and Freitag, S. (2007) Verbrecher im Visier der Experten: Zur Einführung, in Schauz, D. and Freitag, S. (Eds.), Verbrecher im Visier der Experten: Kriminalpolitik zwischen Wissenschaft und Praxis im 19. und frühen 20. Jahrhundert, Stuttgart: Steiner Verlag.

Siebenpfeiffer, H. (2005) Böse Lust: Gewaltverbrechen in Diskursen der Weimarer Republik, Köln: Böhlau.

Siemens, D. (2007) Metropole und Verbrechen: Die Gerichtsreportage in Berlin, Paris, und Chicago 1919-1933, Stuttgart: Steiner Verlag. 
Siemens, D. (2016) Popular Dramas between Transgression and Order: Criminal Trials and their Publics in the Nineteenth and Twentieth Centuries in Global Perspective, in Knepper, P. and Johansen, A. (Eds.), The Oxford Handbook of the History of Crime and Criminal Justice, Oxford: Oxford University Press.

Spierenburg, P. (2016) The Rise of Criminology in its Historical Context, in Knepper, P. and Johansen, A. (Eds.), The Oxford Handbook of the History of Crime and Criminal Justice, Oxford: Oxford University Press.

Tribukait, M. (2017) Gefährliche Sensationen: Die Visualisierung von Verbrechen in deutschen und amerikanischen Pressefotografien 1920-1970, Göttingen: Vandenhoeck \& Ruprecht.

Uhl, K. (2003) Das "verbrecherische" Weib. Geschlecht, Verbrechen und Strafen im kriminologischen Diskurs 1800-1945, Münster: Lit Verlag.

Vyleta, D. (2007) Crime, Jews and News: Vienna, 1895-1914, New York: Berghahn Books.

Wetzell, R. (1996) The Medicalization of Criminal Law Reform in Imperial Germany, in Finzsch, N. and Jütte, R. (Eds.), Institutions of Confinement: Hospitals, Asylums and Prisons in Western Europe and North America, 1500-1950, New York: Cambridge University Press.

Wetzell, R. (2000) Inventing the Criminal: A History of German Criminology 1880-1945, Chapel Hill: University of North Carolina Press.

Wetzell, R. (2004) From Retributive Justice to Social Defense: Penal Reform in Fin-de-Siècle Germany, in Marchand, S. and Lindenfeld, D. (Eds.), Germany at the Fin de Siècle: Culture, Politics, and Ideas, Baton Rouge: Louisiana State University Press.

Wetzell, R. (2008) Die Rolle medizinischer Experten in Strafjustiz und Strafrechtsreformbewegung: Eine Medikalisierung des Strafrechts?, in Kästner, A. and Kesper-Biermann, S. (Eds.), Experten und Expertenwissen in der Strafjustiz von der Frühen Neuzeit bis zur Moderne, Leipzig: Meine-Verlag.

Wetzell, R. (2009) Psychiatry and Criminal Justice in Modern Germany, 1880-1933, Journal of European Studies, 29, p. 270-289.

Wetzell, R., (2010) Gustav Aschaffenburg: German Criminology, in Cullen, F. and Wilcox, P., (Eds.), Enyclopedia of Criminological Theory, Los Angeles: Sage.

Wetzell, R. (2016) Franz von Liszt und die internationale Strafrechtsreformbewegung, in Koch, A. and Löhnig, M. (Eds.), Die Schule Franz von Liszts: Spezialpräventive Kriminalpolitik und die Entstehung des modernen Strafrechts, Tübingen: Mohr Siebeck.

Wetzell, R. (Ed.) (forthcoming, 2019) Criminal Justice in Modern Europe, 1870-1970, Cambridge: Cambridge University Press.

Wiener, M. (1990) Reconstructing the Criminal: Culture, Law and Policy in England, 18301914, Cambridge: Cambridge University Press.

Wiener, M. (2004) Men of Blood: Violence, Manliness, and Criminal Justice in Victorian England, Cambridge: Cambridge University Press.

Wood, J.C. (2012) The Most Remarkable Woman in England: Poison, Celebrity and the Trials of Beatrice Pace, Manchester: Manchester University Press.

Wood, J.C. (2016) Crime News and the Press, in Knepper, P. and Johansen, A. (Eds.), The Oxford Handbook of the History of Crime and Criminal Justice, Oxford: Oxford University Press. 
Wood, J.C and Knepper, P. (2014) Crime stories: criminality, policing and the press in inter-war European and transatlantic perspectives, Media History, 20, 4, p. 345-351.

Ziemann, B., Wetzell, R., Schumann, D. and Brückweh, K. (2012) The scientization of the social in comparative perspective, in Brückweh, K., Schumann, D., Wetzell, R., Ziemann, B. (Eds.), Engineering Society: The Role of the Human and Social Sciences in Modern Societies, 1880-1980, Houndmills: Palgrave Macmillan.

Zimmermann, V. (2017) Race and Ethnicity in German criminology: On crime rates and the Polish population in the Kaiserreich (1871-1914), in Day, L., and Haag, O. (Eds.), The Persistence of Race: Continuity and Change in Germany from the Wilhelmine Empire to National Socialism, New York: Berghahn Books. 